\title{
Hypocapnia and measurement of airflow resistance and dynamic compliance as functions of respiratory frequency
}

\author{
A CUtillo, AH Bigler, R PERONDi, M TURiEl, S WATANABE, \\ AD RENZETTI JR \\ From the Division of Respiratory, Critical Care and Occupational (Pulmonary) Medicine, Department of \\ Medicine, University of Utah College of Medicine, Salt Lake City, USA, and Istituto di Ricerche \\ Cardiovascolari, University of Milan, Italy
}

\begin{abstract}
Measurements of lung mechanical behaviour as a function of respiratory frequency may be associated with significantly increased ventilation at high breathing rates. It follows that these measurements may be influenced by hypocapnia which has been shown to increase airflow resistance and to decrease dynamic compliance. To examine this possibility we continuously monitored the end-tidal $\mathrm{CO}_{2}$ tension during the determination of pulmonary resistance and dynamic compliance as functions of frequency and we compared measurements obtained by the standard method and by a technique designed to prevent the development of hypocapnia at high breathing rates. We studied 11 patients with chronic obstructive pulmonary disease and also two smokers with normal spirometry and resistance. Although conventional measurements at frequencies higher than 40-45 breaths/min were associated with a significant decrease in end-tidal $\mathrm{CO}_{2}$, no systematic differences were found between the values of pulmonary resistance and dynamic compliance obtained by the two techniques. Our data indicate that the development of hypocapnia at high breathing rates does not significantly affect measurements of resistance and compliance as functions of frequency, at least when the duration of each period of hyperventilation is limited to the minimum necessary for a single determination, which was less than 30 seconds in the present study. A comparison of our results with previously published data suggests that the time factor may be critical with respect to the possible effects of hypocapnia on these measurements.
\end{abstract}

Studies of the mechanical behaviour of the lung as a function of respiratory frequency are generally based on measurements performed at different breathing rates at constant tidal volume, so that determinations at high frequencies are associated with significantly increased ventilation. It is therefore possible that these measurements are influenced by hypocapnia, which has been found to increase airflow resistance and to decrease dynamic compliance in both normal subjects and patients with obstructive lung disease. ${ }^{1-6}$ To explore this possibility we studied the changes in end-tidal $\mathrm{CO}_{2}$ tension associated with the determination of lung

Address for reprint requests: Dr Antonio Cutillo, Division of Respiratory, Critical Care and Occupational (Pulmonary) Medicine, University of Utah Medical Center, 50 North Medical Drive, Room 3E544, Salt Lake City, Utah 84132, USA. mechanical behaviour as a function of frequency and we compared measurements of pulmonary resistance and dynamic compliance, performed at high breathing rates, by the conventional method and by a technique designed to prevent the development of hypocapnia.

\section{Methods}

Eleven patients with chronic obstructive pulmonary disease were studied. Their ages, sex, smoking history, spirometric measurements, and pulmonary resistance values (during spontaneous breathing) are given in table 1. Functional residual capacity (FRC) was measured using a constant-volume body plethysmograph. ${ }^{7}$ Normal values were predicted for the static lung volumes from the equations of Goldman and Becklake ${ }^{8}$ and for the forced .. ex- 
Table 1 Age, sex, smoking history, spirometric data, and pulmonary resistance in 11 patients with chronic obstructive pulmonary disease

\begin{tabular}{|c|c|c|c|c|c|c|c|c|}
\hline Subject & Sex & $\begin{array}{l}\text { Age } \\
\text { (yr) }\end{array}$ & $\begin{array}{l}\text { Smoking } \\
\text { history }\end{array}$ & $\begin{array}{l}\text { Vital } \\
\text { capacity } \\
(\% \text { pred })\end{array}$ & $\begin{array}{l}\text { Residual } \\
\text { volume } \\
(\% \text { pred })\end{array}$ & $\begin{array}{l}\text { Total lung } \\
\text { capacity } \\
\text { (\% pred) }\end{array}$ & $\begin{array}{l}\text { Forced expiratory } \\
\text { volume in one second } \\
(\% \text { pred })\end{array}$ & $\begin{array}{l}\text { Pulmonary } \\
\text { resistance } \\
\mathrm{RL} \\
\mathrm{cm} \mathrm{H}_{2} \mathrm{O} /(\mathrm{l} / \mathrm{s})^{*}\end{array}$ \\
\hline LM & $\mathbf{M}$ & 67 & $\mathbf{s}$ & 91 & 234 & 139 & 21 & $2 \cdot 3$ \\
\hline ER & $\mathbf{F}$ & 68 & ns & 71 & 234 & 125 & 36 & $5 \cdot 5$ \\
\hline GF & $\mathbf{M}$ & 72 & s & 79 & 264 & 163 & 33 & $3 \cdot 7$ \\
\hline CI & $\mathbf{M}$ & 67 & $\mathbf{s}$ & 82 & 272 & 172 & 46 & $6 \cdot 9$ \\
\hline FM & $\mathbf{M}$ & 42 & $\mathbf{s}$ & 107 & 167 & 123 & 61 & $5 \cdot 2$ \\
\hline GP & $\mathbf{M}$ & 80 & $\mathbf{s}$ & 84 & 145 & 164 & 45 & $7 \cdot 8$ \\
\hline EM & $\mathbf{M}$ & 63 & $\mathbf{s}$ & 59 & 199 & 118 & 27 & $9 \cdot 9$ \\
\hline GS & $\mathbf{M}$ & 50 & s & 82 & 218 & 128 & 49 & $4 \cdot 5$ \\
\hline EU & $\mathbf{M}$ & 50 & $\mathbf{s}$ & 98 & 360 & 184 & 35 & $3 \cdot 7$ \\
\hline IR & $\mathbf{M}$ & 61 & $\mathbf{s}$ & 78 & 208 & 124 & 50 & $4 \cdot 8$ \\
\hline FP & $\mathbf{M}$ & 59 & $\mathbf{s}$ & 57 & 185 & 139 & 24 & $4 \cdot 0$ \\
\hline
\end{tabular}

s = smoker; ns = nonsmoker.

*Conversion to SI units: RL: $1 \mathrm{~cm} \mathrm{H} \mathrm{H}_{2} \mathrm{O} /(1 / \mathrm{s})=0.098 \mathrm{kPa} /(1 / \mathrm{s})$.

piratory volume in one second $\left(\mathrm{FEV}_{1}\right)$ from Berglund et al. ${ }^{9}$ The results of experiments performed on two male smokers (AS, age 32 years, and GR, age 38 years) with normal spirometric and pulmonary resistance values are also reported.

Studies of lung mechanical behaviour as a function of respiratory frequency were performed, with some modifications, as described elsewhere. ${ }^{10}$ Pulmonary resistance ( $\mathrm{RL}_{\mathrm{L}}$ ) was measured by the method of electrical subtraction of Mead and Whittenberger, ${ }^{11}$ each measurement of $\mathrm{RL}$ corresponding to the value obtained from a single pressure-flow tracing (two or three consecutive breaths). Dynamic compliance (Cdyn) was determined from simultaneously recorded tracings of tidal volume and transpulmonary pressure, each measurement representing the average of the inspiratory values obtained from 5-15 breaths. The frequency response of the flow-metre-integrator system was determined as described elsewhere. ${ }^{10}$ The amplitude response of the various components was uniform $( \pm 5 \%)$ at least up to a frequency of 2.5 cycles $/ \mathrm{s}$ and no phase shifts between flow or volume and oesophageal pressure were detectable up to this frequency.

The subjects were studied while sitting in the body plethysmograph; they were instructed to breathe at various respiratory frequencies without significantly changing the level of lung inflation or tidal volume. The duration of each period of breathing at an imposed frequency was limited to the minimum necessary to record a single pressure-flow tracing for the measurement of $R L$, or 10-20 breaths for that of Cdyn (less than $30 \mathrm{~s}$ at frequencies higher than 40-45 breaths/min). Each determination was followed by an adequate period of spontaneous breathing to allow recovery to basal conditions. In each subject $\mathrm{RL}_{\mathrm{L}}$ or Cdyn or both were measured at frequencies generally ranging between 8-10 and 5060 breaths/min; beyond these limits most subjects tended to significantly change the tidal volume or the level of lung inflation or both. Measurements of $R_{L}$ and Cdyn were discarded when the tidal volume deviated more than $50 \%$ from the average value during spontaneous breathing, or the end-expiratory level shifted more than 0.5 litre. The coefficient of variation ranged from 8.3 to $25.6 \%$ for the tidal volume, and from 3.6 to $9.4 \%$ for FRC (plethysmographic method). The coefficient of variation of repeated measurements during spontaneous breathing was 4.9 to $19.7 \%$ for $R_{L}$ and 5.8 to $14.5 \%$ for Cdyn.

The $\mathrm{CO}_{2}$ concentration of respired gas sampled at the mouthpiece was measured with an infrared analyser (Capnograph Godart) to obtain a continuous recording of end-tidal $\mathrm{CO}_{2}$ concentration; the corresponding data were expressed as end-tidal $\mathrm{CO}_{2}$ tension $\left(\mathrm{PETCO}_{2}\right)$. The $90 \%$ response time of the $\mathrm{CO}_{2}$-recording system (including the tubing from mouthpiece to analyser) was approximately $0 \cdot 2-0 \cdot 3 \mathrm{~s}$. Measurements of $\mathrm{RL}$ and Cdyn at high respiratory frequencies were made: (a) following the standard technique described above; (b) with the subject inhaling $\mathrm{CO}_{2}$ in air to prevent the development of hypocapnia. Since the inspiratory $\mathrm{CO}_{2}$ concentration required to maintain $\mathrm{PETCO}_{2}$ constant varied with tidal volume and respiratory frequency, a controlled flow of $\mathrm{CO}_{2}$ in air was added to the inspired gas at a measured distance from the opening of the instrumental airway (to ensure proper mixing of the two gas streams). The $\mathrm{CO}_{2}$ flow could be adjusted using a variable-speed pump. By this technique $\mathrm{PETCO}_{2}$ could generally be maintained at a level very close to that observed during spontaneous breathing. All observations associated with a value more than $5 \mathrm{mmHg}(0.7 \mathrm{kPa})$ above or below this 
Table 2 Hypocapnia and measurement of $R \mathrm{~L}$ at high breathing rates

\begin{tabular}{|c|c|c|c|c|c|c|c|c|c|c|}
\hline Subjects & $\begin{array}{l}R \mathbf{L} \\
\text { as a function } \\
\text { of } f\end{array}$ & Treatment & $\begin{array}{l}\mathrm{CO}_{2} \\
\text { technique }\end{array}$ & $\begin{array}{l}\mathrm{PETCO}_{2} \\
\text { spontaneous } \\
\text { breathing } \\
\text { mm } \mathrm{Hg}\end{array}$ & $\begin{array}{l}\mathrm{PETCO}_{2} \\
\text { high } \\
\text { frequencies } \\
\mathrm{mmHg}\end{array}$ & $\begin{array}{l}\text { Frequency } \\
\text { breaths/ } \\
\text { min }\end{array}$ & $F$ test $\dagger$ & $\begin{array}{l}R \mathrm{~L} \\
\mathrm{~cm} \mathrm{H}_{2} \mathrm{O} /(\mathrm{l} / \mathrm{s})\end{array}$ & $F$ test & $\begin{array}{l}\text { F test } \\
\text { adjusted } \\
\text { means }\end{array}$ \\
\hline $\mathbf{L M}$ & f-dep & & $\begin{array}{l}\text { hypo } \\
\text { iso } \\
\text { hypo }\end{array}$ & $39 \cdot 5 \pm 1 \cdot 0$ & $\begin{array}{l}31 \cdot 7 \pm 3 \cdot 3 \\
37 \cdot 9 \pm 1 \cdot 2 \\
28 \cdot 4+0.7\end{array}$ & $\begin{array}{l}42 \pm 12 \\
40 \pm 7 \\
36 \pm 5\end{array}$ & NS & $\begin{array}{l}2 \cdot 4 \pm 0.4 \\
2 \cdot 3 \pm 0.3 \\
4 \cdot 9 \pm 0.2\end{array}$ & NS & \\
\hline ER & f-dep & & $\begin{array}{l}\text { hypo } \\
\text { iso } \\
\text { hypo }\end{array}$ & $\begin{array}{l}33.8 \pm 0.8 \\
30.6+0.4\end{array}$ & $\begin{array}{l}28.4 \pm 0.7 \\
33.4 \pm 1.1 \\
22.4 \pm 1.5\end{array}$ & $\begin{array}{l}36 \pm 5 \\
48 \pm 5 \\
44 \pm 9\end{array}$ & $\mathrm{p}<0.05$ & $\begin{array}{l}4 \cdot 9 \pm 0 \cdot 2 \\
5 \cdot 7 \pm 0 \cdot 3 \\
6 \cdot 1 \pm 0 \cdot 4\end{array}$ & $p<0.05$ & NS \\
\hline GP & f-dep & & $\begin{array}{l}\text { iso } \\
\text { hypo }\end{array}$ & $30.0 \pm 0.5$ & $\begin{array}{l}30.8 \pm 2.4 \\
21 \cdot 3 \pm 1 \cdot 2\end{array}$ & $\begin{array}{l}49 \pm 6 \\
55 \pm 8\end{array}$ & NS & $\begin{array}{l}7 \cdot 2 \pm 0.8 \\
6 \cdot 5 \pm 0.4\end{array}$ & $\mathrm{p}<0.05$ & $\mathrm{p}<0.05$ \\
\hline & fden & & iso & $25,2+1,8$ & $32.9 \pm 4.3$ & $59 \pm 2$ & NS & $6 \cdot 3 \pm 0.3$ & NS & \\
\hline EM & f-dep & $\mathrm{O}$ & $\begin{array}{l}\text { hypo } \\
\text { iso } \\
\text { hypo }\end{array}$ & $35 \cdot 3 \pm 1 \cdot 8$ & $\begin{array}{l}28 \cdot 6 \pm 1 \cdot 6 \\
34 \cdot 3 \pm 2 \cdot 0 \\
25 \cdot 7 \pm 2.0\end{array}$ & $\begin{array}{l}37 \pm 5 \\
40 \pm 4 \\
39 \pm 4\end{array}$ & NS & $\begin{array}{l}9 \cdot 0 \pm 0.9 \\
8 \cdot 4 \pm 0.8 \\
7 \cdot 1 \pm 0.8\end{array}$ & NS & \\
\hline GS & f-dep & $\mathrm{O}$ & $\begin{array}{l}\text { iso } \\
\text { hypo }\end{array}$ & $22.8 \pm 0.6$ & $\begin{array}{l}36.8 \pm 4.6 \\
16.7 \pm 0.7\end{array}$ & $\begin{array}{l}46 \pm 6 \\
52 \pm 9\end{array}$ & $p<0.05$ & $\begin{array}{l}6.8 \pm 0.6 \\
4.4 \pm 0.7\end{array}$ & NS & NS \\
\hline & f-dep & A & $\begin{array}{l}\text { iso } \\
\text { hypo }\end{array}$ & $21 \cdot 1 \pm 0 \cdot 3$ & $\begin{array}{l}22.4 \pm 1.6 \\
15.2 \pm 1.0\end{array}$ & $\begin{array}{l}66 \pm 9 \\
57 \pm 13\end{array}$ & $\mathrm{p}<0.05$ & $\begin{array}{l}4.7 \pm 0.4 \\
4.1 \pm 0.4\end{array}$ & NS & NS \\
\hline EU & f-indep & $\mathbf{A}$ & $\begin{array}{l}\text { iso } \\
\text { hypo }\end{array}$ & $22 \cdot 2 \pm 0.9$ & $\begin{array}{l}19.9 \pm 0.9 \\
15.8 \pm 1.3\end{array}$ & $\begin{array}{l}63 \pm 8 \\
55 \pm 11\end{array}$ & NS & $\begin{array}{l}4 \cdot 3 \pm 0.8 \\
4 \cdot 0 \pm 0.4\end{array}$ & NS & \\
\hline & f-indep & $\mathbf{A}$ & $\begin{array}{l}\text { iso } \\
\text { hypo }\end{array}$ & $20.6 \pm 1.0$ & $\begin{array}{l}21.6 \pm 3.3 \\
12.5 \pm 1.7\end{array}$ & $\begin{array}{l}45 \pm 11 \\
47 \pm 11\end{array}$ & NS & $\begin{array}{l}3.5 \pm 0.1 \\
2.8 \pm 0.3\end{array}$ & $p<0.05$ & $\mathrm{p}<0.05$ \\
\hline & & A & iso & & $19 \cdot 7 \pm 1 \cdot 4$ & $39 \pm 6$ & NS & $2 \cdot 4 \pm 0 \cdot 1$ & $\mathrm{p}<0.05$ & $p<0.05$ \\
\hline
\end{tabular}

$\mathrm{RL}=$ pulmonary resistance $;$ Cdyn $=$ dynamic compliance $; \mathrm{f}=$ respiratory frequency; $\mathrm{f}$-dep $=$ frequency dependent $; \mathrm{f}$-indep $=$ independen of frequency; statistical significance of the changes in $\mathrm{RL}$ or $\mathrm{Cdyn}$ with $\mathrm{f}$ was assessed by linear or curvilinear regression analysis ${ }^{10}$; $\mathrm{PETCO}_{2}=$ end-tidal $\mathrm{CO}_{2}$ tension; hypo $=$ hypocapneic ventilation; iso = isocapneic ventilation; $\mathrm{O}=$ after orciprenaline; $\mathrm{A}=$ after atropine; $\mathrm{F}$-test $=$ test of significance of differences between mean values of frequency $(t)$ and $R L$ or Cdyn $\left(\begin{array}{l}+ \\ +\end{array}\right)$, comparing hypo- and isocapneic techniques (analysis of variance); F-test, adjusted means = test of significance of differences between mean values of RL or Cdyn (comparing hypo- and isocapneic techniques) adjusted for differences in $\mathrm{f}$ (analysis of covariance). NS = not significant.

Values of $\mathrm{PETCO}_{2}, \mathrm{f}, \mathrm{RL}$ and Cdyn are expressed as means $\pm \mathrm{SD}$.

Conversion to SI units: $1 \mathrm{mmHg}=0.133 \mathrm{kPa} ; \mathrm{RL}: 1 \mathrm{~cm} \mathrm{H}_{2} \mathrm{O} /(\mathrm{l} / \mathrm{s})=0.098 \mathrm{kPa} /(1 / \mathrm{s}) ; \mathrm{Cdyn}: 11 / \mathrm{cm} \mathrm{H}_{2} \mathrm{O}=10 \cdot 2 \mathrm{l} / \mathrm{kPa}$.

Table 3 Hypocapnia and measurement of Cdyn at high breathing rates

\begin{tabular}{|c|c|c|c|c|c|c|c|c|c|c|}
\hline Subjects & $\begin{array}{l}\text { Cdyn } \\
\text { as a function } \\
\text { of } f\end{array}$ & Treatment & $\begin{array}{l}\mathrm{CO}_{2} \\
\text { technique }\end{array}$ & $\begin{array}{l}\text { PETCO }_{2} \\
\text { spontaneous } \\
\text { breathing } \\
(\mathrm{mmHg})\end{array}$ & $\begin{array}{l}P_{\mathrm{ETCO}} \\
\text { high frequencies } \\
(\mathrm{mmHg})\end{array}$ & $\begin{array}{l}\text { Frequency } \\
\text { breaths/min }\end{array}$ & F test $\dagger$ & $\begin{array}{l}\mathrm{Cdyn} \\
\mathrm{I} / \mathrm{cm} \mathrm{H} \mathrm{H}_{2} \mathrm{O}\end{array}$ & F test $t_{+}^{+}$ & $\begin{array}{l}\text { F test } \\
\text { adjusted } \\
\text { means }\end{array}$ \\
\hline AS & f-dep & & $\begin{array}{l}\text { hypo } \\
\text { iso }\end{array}$ & $34.9 \pm 1.9$ & $\begin{array}{l}23 \cdot 4 \pm 2 \cdot 6 \\
32 \cdot 8+1 \cdot 1\end{array}$ & $\begin{array}{l}48 \pm 10 \\
43+6\end{array}$ & NS & $\begin{array}{l}0.246 \pm 0.058 \\
0.233+0.029\end{array}$ & NS & \\
\hline GR & f-indep & & $\begin{array}{l}\text { hypo } \\
\text { iso }\end{array}$ & $32 \cdot 8 \pm 1 \cdot 0$ & $\begin{array}{l}24.6 \pm 3.2 \\
30.2 \pm 1.9\end{array}$ & $\begin{array}{l}38 \pm 8 \\
42 \pm 9\end{array}$ & NS & $\begin{array}{l}0.245 \pm 0.023 \\
0.263 \pm 0.021\end{array}$ & NS & \\
\hline & f-indep & $\mathbf{A}$ & hypo & $40 \cdot 2 \pm 0 \cdot 0$ & $32 \cdot 0 \pm 2 \cdot 3$ & $43 \pm 4$ & NS & $0.224 \pm 0.036$ & NS & \\
\hline GF & f-dep & A & $\begin{array}{l}\text { ISo } \\
\text { hypo } \\
\text { iso }\end{array}$ & $34.5 \pm 0.0$ & $\begin{array}{l}38 \cdot 5 \pm 1 \cdot 1 \\
26 \cdot 0 \pm 2 \cdot 0 \\
33 \cdot 5+0.9\end{array}$ & $\begin{array}{l}44 \pm 4 \\
53 \pm 12 \\
55+3\end{array}$ & NS & $\begin{array}{l}0.246 \pm 0.030 \\
0.109 \pm 0.051\end{array}$ & NS & \\
\hline FM & f-dep & & $\begin{array}{l}\text { hypo } \\
\text { iso }\end{array}$ & $35 \cdot 0 \pm 1 \cdot 9$ & $\begin{array}{l}25.6 \pm 2.7 \\
34.8 \pm 3.3\end{array}$ & $\begin{array}{l}45 \pm 5 \\
47 \pm 8\end{array}$ & NS & $0.114 \pm 0.015$ & NS & \\
\hline IR & f-dep & & $\begin{array}{l}\text { hypo } \\
\text { iso }\end{array}$ & $29 \cdot 0 \pm 1 \cdot 4$ & $\begin{array}{l}19 \cdot 4 \pm 1 \cdot 5 \\
31 \cdot 2 \pm 2 \cdot 4\end{array}$ & $\begin{array}{l}40 \pm 9 \\
48 \pm 3\end{array}$ & NS & $\begin{array}{l}0.073 \pm 0.006 \\
0.060 \pm 0.008\end{array}$ & $\mathrm{p}<0.05$ & NS \\
\hline FP & f-dep & $\mathbf{A}$ & $\begin{array}{l}\text { hypo } \\
\text { iso } \\
\text { hypo }\end{array}$ & $32 \cdot 5 \pm 1 \cdot 8$ & $\begin{array}{l}23 \cdot 3 \pm 2 \cdot 3 \\
33 \cdot 0 \pm 3 \cdot 0 \\
25 \cdot 5 \pm 2 \cdot 3\end{array}$ & $\begin{array}{l}38 \pm 7 \\
31 \pm 6 \\
36 \pm 6\end{array}$ & NS & $\begin{array}{l}0.077 \pm 0.005 \\
0.072 \pm 0.010 \\
0.071 \pm 0.003\end{array}$ & NS & \\
\hline & & $\mathbf{A}$ & iso & & $33.7 \pm 1.4$ & $33 \pm 1$ & NS & $0.075 \pm 0.002$ & NS & \\
\hline
\end{tabular}


level were discarded, since it has been previously shown that relatively small variations in PeTCO$_{2}$ (less than $10 \mathrm{mmHg}$ or $1.3 \mathrm{kPa}$ ) may be followed by significant changes in $\mathrm{RL}^{5}$ The difference between the mean values of $\mathrm{PETCO}_{2}$ during spontaneous breathing and those obtained at high frequencies using the $\mathrm{CO}_{2}$-inhalation technique ranged between 0 and $3.1 \mathrm{mmHg}(0-0.4 \mathrm{kPa})$. Measurements using the two techniques could be obtained at closely comparable frequencies in most experiments. Occasionally more marked differences were observed between the frequency values corresponding to the two experimental conditions and these differences were taken into account in the statistical analysis of the results. With respect to the level of lung inflation, no significant differences were found between measurements performed by the two techniques.

In five subjects the relationships between lung
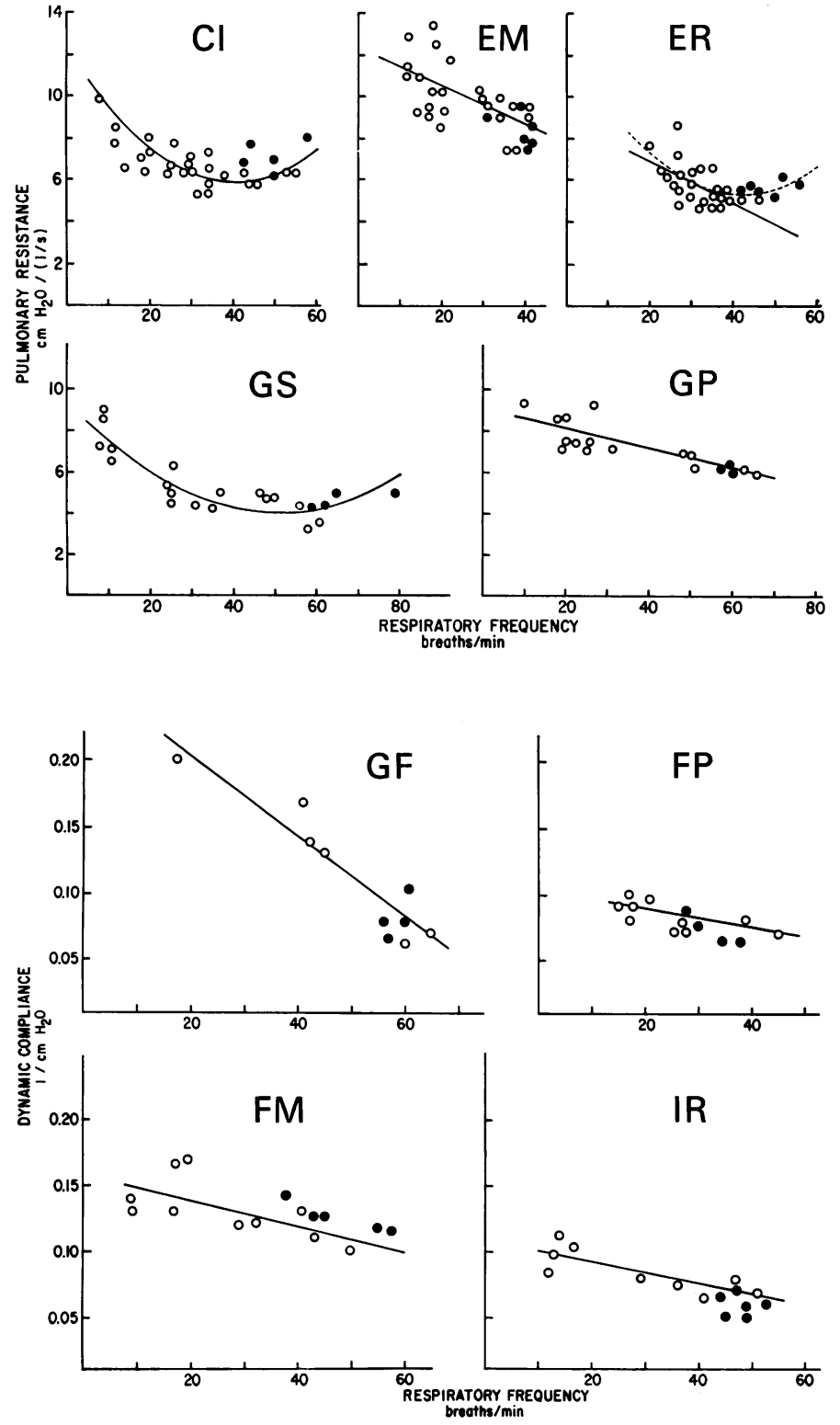

Fig 1 Pulmonary resistance $(R \mathrm{~L})$ as a function of respiratory frequency in five patients with chronic obstructive pulmonary disease: measurements performed by the conventional method (O) and by a $\mathrm{CO}_{2}$ inhalation technique, to prevent the development of hypocapnia at high frequencies (๑). The continuous lines represent linear or curvilinear regressions fitted to the data obtained by the conventional method. The dashed line (patient ER) represents a curvilinear regression fitting all experimental data (conventional and $\mathrm{CO}_{2}$ inhalation measurements). Conversion to SI units: $R \mathrm{~L}$ : $1 \mathrm{cmH}_{2} \mathrm{O} /(\mathrm{l} / \mathrm{s})=0.098 \mathrm{kPa} /(\mathrm{l} / \mathrm{s})$.
Fig 2 Dynamic compliance (Cdyn) as a function of respiratory frequency in four patients with chronic obstructive pulmonary disease: measurements performed by the conventional method (O) and by a $\mathrm{CO}_{2}$ inhalation technique, to prevent the development of hypocapnia at high frequencies (৩). The lines represent linear regressions fitted to the data obtained by the conventional method. Conversion to SI units: Cdyn: $1 \mathrm{l} / \mathrm{cmH} \mathrm{H}_{2} \mathrm{O}=10 \cdot 2 \mathrm{l} / \mathrm{kPa}$. 
mechanical properties and respiratory frequency were studied before and after intravenous administration of $1.1 .5 \mathrm{mg}$ of atropine sulphate, or inhalation of $1 \mathrm{ml}$ of $2 \%$ orciprenaline sulphate solution; the orciprenaline solution was administered using a nebuliser (Bird Micronebuliser) driven by compressed air.

The results were analysed by standard statistical methods. ${ }^{12}$

\section{Results}

The results of conventional studies of the relationships between lung mechanical properties and respiratory frequency are given in tables 2 and 3 . As expected $\mathrm{PeTCO}_{2}$ decreased with increasing respiratory frequency. When quantified by regression analysis, the decrease in $\mathrm{PETCO}_{2}$ per unit change in frequency was $0.18-0.33 \mathrm{mmHg}(0.02-0.04 \mathrm{kPa})$ for the $\mathrm{RL}_{\mathrm{L}}$ measurements and $0.24-0.47 \mathrm{mmHg}(0.03$ $0.06 \mathrm{kPa}$ ) for the Cdyn measurements. Tables 2 and 3 also show that in most experiments, before and after bronchodilator, the values of $R_{L}$ or Cdyn obtained by the $\mathrm{CO}_{2}$ inhalation technique were not significantly different from those measured by the standard method, when differences in respiratory frequency between the two procedures were taken into account (analysis of covariance: $F$ test of adjusted means). Small, non-uniform discrepancies were only occasionally observed (see table $2, R_{L}$ measurements). The results of some experiments are illustrated graphically in figs 1 and 2.

\section{Discussion}

In our subjects, conventional measurements of $R_{L}$ and Cdyn at frequencies higher than 40-45 breaths/ min were generally associated with a significant fall in end-tidal $\mathrm{CO}_{2}$ tension. Similar end-expiratory $\mathrm{CO}_{2}$ tension levels, attained by voluntary hyperventilation, have been found to increase airflow resistance and to decrease dynamic compliance in normal subjects and in patients with chronic obstructive pulmonary disease. ${ }^{135}$ In the present study however, the values of $\mathrm{RL}$ determined by the standard procedure were generally not significantly different from those obtained using the $\mathrm{CO}_{2-}$ inhalation technique to prevent the development of hypocapnia (when discrepancies in frequency were allowed for). As shown in table 2, small differences occasionally observed between the values of $\mathrm{RL}_{\mathrm{L}}$ obtained by the two techniques were not uniform and in patient EU were unaffected by atropine, which has been shown to prevent or reduce the bronchial response to hypocapnia. ${ }^{135}$ These findings suggest that factors other than hypocapnia may have been responsible for the discrepancy. Even if statistically significant, these occasional differences appear to be of little practical importance for the purposes of the present study.

Although, compared with RL, determinations of Cdyn were based on a larger number of breaths, and were generally associated with a more marked decrease in $\mathrm{PETCO}_{2}$, analysis of the values of Cdyn showed no differences between the conventional method and the $\mathrm{CO}_{2}$-inhalation technique when frequency was taken into account. Furthermore, single-breath values of Cdyn showed no appreciable tendency to change during each determination.

In conclusion, the present data indicate that the development of hypocapnia during rapid breathing does not substantially affect the conventional measurement of $\mathrm{RL}$ and Cdyn as functions of respiratory rate, at least under the experimental conditions of the present study; thus special measures designed to prevent the fall in $\mathrm{CO}_{2}$ tension appear to be unnecessary. It seems possible that in some of our measurements at high respiratory frequencies the level of hypocapnia was insufficiently low to evoke a bronchial response. However, a comparison of our results with those of previous studies $^{135}$ suggests that the duration of the period of rapid respiration may be critical, with respect to the effects of hypocapnia on the measurement of $R L$ and Cdyn. In the present experiments, the duration of each measurement was less than $30 \mathrm{~s}$ (from the onset of rapid breathing) at frequencies exceeding 40-45 breaths/min. Studies of the time course of the response to hypocapnia have shown that changes in lung mechanics may occur within the first minute of hyperventilation. ${ }^{5}$ This suggests a relatively narrow safety margin with respect to the prevention of possible effects of hypocapnia in conventional studies of frequency dependence.

\section{References}

${ }^{1}$ Newhouse MT, Becklake MR, Macklem PT, McGregor $M$. Effect of alterations in end-tidal $\mathrm{CO}_{2}$ tension on flow resistance. J Appl Physiol 1964;19:745-9.

${ }^{2}$ Pirnay F, Damoiseau J, Petit JM. Influence de l'alcalose gazeuse sur les propriétés mécaniques pulmonaires de l'homme normal. Int $Z$ Angewandte Physiol 1964;20: 420-6.

${ }^{3}$ Sterling GM. The mechanism of bronchoconstriction due to hypocapnia in man. Clin Sci 1968;34:277-85.

4 Fisher HK, Holton P, Buxton R St J, Nadel JA. Resistance to breathing during exercise-induced asthma attacks. Am Rev Respir Dis 1970;101:885-96.

' Cutillo A, Omboni E, Perondi R, Tana F. Effect of hypocapnia on pulmonary mechanics in normal subjects and in patients with chronic obstructive lung disease. Am Rev Respir Dis 1974;110:25-33.

${ }^{6} \mathrm{O}$ 'Cain CF, Hensley MJ, McFadden ER Jr, Ingram RH Jr. 
Pattern and mechanism of airway response to hypocapnia in normal subjects. J Appl Physiol 1979;47:8-12.

7 DuBois AB, Botelho SY, Bedell GN, Marshall R, Comroe JH Jr. A rapid plethysmographic method for measuring thoracic gas volume: a comparison with a nitrogen washout method for measuring functional residual capacity in normal subjects. J Clin Invest 1956;35:322-6.

${ }^{8}$ Goldman HI, Becklake MR. Respiratory function tests: normal values at median altitudes and the prediction of normal results. Am Rev Tuberc 1959;79:457-67.

${ }^{9}$ Berglund E, Birath G, Bjure J et al. Spirometric studies in normal subjects. I. Forced expirograms in subjects between 7 and 70 years of age. Acta Med Scand 1963; 173:185-92.

${ }^{10}$ Cutillo A, Omboni E, Perondi R, Tana F. Pulmonary resistance and respiratory frequency in chronic airways obstruction. J Appl Physiol 1973;35:122-8.

${ }^{11}$ Mead J, Whittenberger JL. Physical properties of human lungs measured during spontaneous respiration. $J$ Appl Physiol 1952/53;5:779-96.

12 Snedecor GW, Cochran WG. Statistical methods. Ames, Iowa: Iowa State University Press, 1967. 